\title{
The impact of African Swine Fever Virus on smallholder village pig production: an outbreak investigation in Lao PDR
}

Nina Matsumoto $^{1}$, J Siengsanan-Lamont ${ }^{2}$, Tariq Halasa ${ }^{3}$, James Young ${ }^{1}$, Michael Ward ${ }^{1}$, Bounlom douangngeun ${ }^{4}$, Watthana theppangna ${ }^{4}$, Syseng Khounsy ${ }^{4}$, Jenny-Ann Toribio ${ }^{1}$, Russell Bush ${ }^{1}$, and S.D. Blacksell ${ }^{2}$

${ }^{1}$ The University of Sydney School of Veterinary Science

${ }^{2}$ Mahidol Oxford Tropical Medicine Research Unit

${ }^{3}$ Section of Animal welfare and Disease Control Department of Veterinary and Animal

Sciences Faculty of Health and Medical Sciences University of Copenhagen 1870

Frederiksberg C Denmark

${ }^{4}$ Ministry of Agriculture and Forestry

May 15, 2021

\begin{abstract}
African Swine Fever Virus (ASFV) causes a deadly disease of pigs which spread through southeast Asia in 2019. We investigated one of the first outbreaks of ASFV in Lao Peoples Democratic Republic amongst smallholder villages of Thapangtong District, Savannakhet Province. In this study, two ASFV affected villages were compared to two unaffected villages. Evidence of ASFV-like clinical signs appeared in pig herds as early as May 2019, with median epidemic days on 1 and 18 June in the two villages, respectively. Using participatory epidemiology mapping techniques, we found statistically significant spatial clustering in both outbreaks $(\mathrm{P}<0.001)$. Villagers reported known risk factors for ASFV transmission - such as free-ranging management systems and wild boar access - in all four villages. The villagers reported increased pig trader activity from Vietnam before the outbreaks; however, the survey did not determine a single outbreak source. The outbreak caused substantial household financial losses with an average of 9 pigs lost to the disease, and Monte Carlo analysis estimated this to be USD 215 per household. ASFV poses a significant threat to food and financial security in smallholder communities such as Thapangtong, where $40.6 \%$ of the district's population are affected by poverty. This study shows ASFV management in the region will require increased local government resources, knowledge of informal trader activity and wild boar monitoring alongside education and support to address intra-village risk factors such as free-ranging, incorrect waste disposal and swill feeding.
\end{abstract}

\section{Hosted file}

TBED-MainTextReviewed_CLEAN_ROUND2.pdf available at https://authorea.com/users/413889/ articles/522071-the-impact-of-african-swine-fever-virus-on-smallholder-village-pigproduction-an-outbreak-investigation-in-lao-pdr

\section{Hosted file}

ThapangtongOutbreak_Figure1.pdf available at https://authorea.com/users/413889/articles/ 522071-the-impact-of-african-swine-fever-virus-on-smallholder-village-pig-production-anoutbreak-investigation-in-lao-pdr

\section{Hosted file}


ThapangtongOutbreak_Figure2.pdf available at https://authorea.com/users/413889/articles/ 522071-the-impact-of-african-swine-fever-virus-on-smallholder-village-pig-production-anoutbreak-investigation-in-lao-pdr

\section{Hosted file}

ThapangtongOutbreak_Figure3.pdf available at https://authorea.com/users/413889/articles/ 522071-the-impact-of-african-swine-fever-virus-on-smallholder-village-pig-production-anoutbreak-investigation-in-lao-pdr

\section{Hosted file}

ThapangtongOutbreak_Figure4.pdf available at https://authorea.com/users/413889/articles/ 522071-the-impact-of-african-swine-fever-virus-on-smallholder-village-pig-production-anoutbreak-investigation-in-lao-pdr

\section{Hosted file}

ThapangtongOutbreak_Figure5.pdf available at https://authorea.com/users/413889/articles/ 522071-the-impact-of-african-swine-fever-virus-on-smallholder-village-pig-production-anoutbreak-investigation-in-lao-pdr

\section{Hosted file}

ThapangtongOutbreak_Figure6.pdf available at https://authorea.com/users/413889/articles/ 522071-the-impact-of-african-swine-fever-virus-on-smallholder-village-pig-production-anoutbreak-investigation-in-lao-pdr

\section{Hosted file}

ThapangtongOutbreak_Table2 (updated v2).pdf available at https://authorea.com/users/413889/ articles/522071-the-impact-of-african-swine-fever-virus-on-smallholder-village-pigproduction-an-outbreak-investigation-in-lao-pdr

\section{Hosted file}

ThapangtongOutbreak_Table1 (updated v2).pdf available at https://authorea.com/users/413889/ articles/522071-the-impact-of-african-swine-fever-virus-on-smallholder-village-pigproduction-an-outbreak-investigation-in-lao-pdr 